
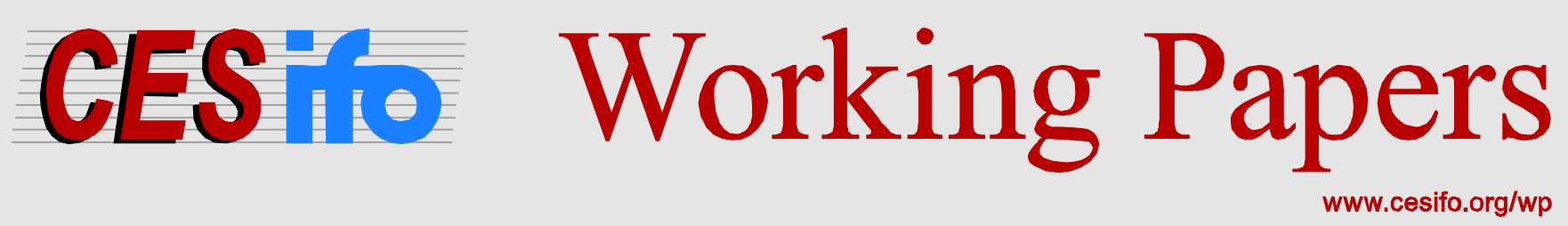

\title{
Early-life Circumstances Predict Measures of Trust among Adults: Evidence from Hunger Episodes in Post-War Germany
}

\author{
Maximiliane Hörl \\ Iris Kesternich \\ James P. Smith \\ Joachim K. Winter
}

CESIFO WORKING PAPER NO. 6093

CATEGORY 13: BEHAVIOURAL ECONOMICS

SEPTEMBER 2016

An electronic version of the paper may be downloaded

- from the SSRN website:

- from the RePEc website:

wWw.SSRN.com

- from the CESifo website:

www.RePEc.org

www.CESifo-group.org/wp

\section{CESifo}




\title{
Early-life Circumstances Predict Measures of Trust among Adults: Evidence from Hunger Episodes in Post-War Germany
}

\begin{abstract}
Can a major shock in childhood permanently shape trust? We consider a hunger episode in Germany after WWII and construct a measure of hunger exposure from official data on caloric rations set monthly by the occupying forces providing regional and temporal variation. We correlate hunger exposure with measures of trust using data from a nationally representative sample of the German population. We show that individuals exposed to low caloric rations in childhood have significantly lower levels of trust as adults. This finding highlights that early-life experiences can have long-term effects in domains other than health, where such effects are well-documented.
\end{abstract}

JEL-Codes: D010, D740, J100, J620, N440, Z130.

Keywords: trust, endogenous preferences, hunger, war.

\author{
Maximiliane Hörl \\ Ludwig-Maximilians-University \\ Germany-80539 Munich \\ maximiliane.hoerl@econ.lmu.de \\ James P. Smith \\ RAND Corporation \\ USA - CA 90407-2138 Santa Monica \\ smith@rand.org
}

\author{
Iris Kesternich \\ KU Leuven \\ Belgium - 3000 Leuven \\ iris.kesternich@Irz.uni-muenchen.de \\ Joachim K. Winter \\ Ludwig-Maximilians-University \\ Germany-80539 Munich \\ winter@lmu.de
}

The data in this publication were made available to us by the German Socio-Economic Panel Study (SOEP) at the German Institute for Economic Research (DIW), Berlin. We thank seminar audiences at Harvard Health Care Policy, the Harvard Center of Population, IUPUI, the University of Stirling, and the Workshop of New Empirical Developments in Health and Labor Markets for helpful comments and suggestions. Financial support through the International Doctoral Program "Evidence-Based Economics" of the Elitenetzwerk Bayern (Hörl); the research funds of KU Leuven (Kesternich); and the National Institute on Aging (Smith) is gratefully acknowledged. 


\section{Introduction}

Trust has a decisive role in many human interactions. For example, when we consider whether to engage in some form of cooperation with others, it is crucial whether we believe this person is trustworthy (Gambetta, 2000). Societies with higher levels of trust tend to have better government institutions and thus higher economic growth (La Porta et al., 1997; Knack and Keefer, 1997). Furthermore, measures of trust are important predictors of economic activity in such diverse areas as stock market participation (Guiso et al., 2008) and international trade and investments (Guiso et al., 2009). Not much is known, however, about the underlying determinants of trust and the reasons for the observed heterogeneity among people.

In this paper, we study in a life-course perspective (Elder, 1998) whether a major shock on individual experiences early in life - specifically, the exposure to the experience of hunger predicts trust later in adult life. We construct a measure of exposure to hunger in Germany after the Second World War (WWII) from data on caloric rations that were set monthly by the occupying forces in the four occupation zones. We combine these exposure measures with data from a random sample of the adult German population and document that individuals who were exposed to low caloric rations in their childhood and youth show significantly lower levels of trust many years after the hunger experience.

Our analysis is motivated by a recent wave of research showing that early-life circumstances and shocks, even those experienced in utero, do not only predict adult health outcomes (Barker, 1992, 2004; Almond and Currie, 2011; van den Berg et al., 2015) but also socio-economic outcomes later in life. Adult outcomes affected by such shocks as the experience of war or exposure to prolonged periods of hunger early in life include education and labor market status (Goodman et al., 2011; Juerges, 2013; Kesternich et al., 2014), preferences for food consumption (Kesternich 
et al., 2015), the development of egalitarian motivations (Bauer et al., 2014), and subjective wellbeing (Bertoni, 2015). ${ }^{1}$

This study is also related to an emerging literature in economics arguing that the societal and institutional environment an individual experiences over the course of her life can change preferences and expectations (Fehr and Hoff, 2011; Malmendier and Nagel, 2011, 2016; Black et al., 2015; Malmendier and Shen, 2015). More specifically with respect to social preferences and trust, Putnam et al. (1994) and Bigoni et al. (2015) argue that historical events have shaped preferences for cooperation in Southern and Northern Italy differentially and that the resulting preference heterogeneity can account for the fact that individuals in the South and North react differently to similar institutions and incentives. Also, East and West Germans have been shown to differ in measures of trust and convergence after reunification has been at most very slow, which has been interpreted as the political system shaping trust (Rainer and Siedler, 2009).

Despite these recent advances, evidence on the determinants of heterogeneity in trust preferences is still scarce. In particular, it has been difficult to link variation in historical events to variation in trust preferences. In this paper, we exploit the natural experiment induced by variations in caloric supply across regions and over time in the year immediately after the end of WWII in Germany to study this link. Our analysis shows that about one-fifth of the differences in East and West Germany levels of trust go back to the stronger exposure to hunger of East Germans after WWII.

The remainder of this paper is structured as follows. In section 2 , we describe the data, the measures of trust and exposure to hunger, and the statistical framework. Section 3 contains the results. We conclude with a discussion of our findings in Section 4.

\footnotetext{
${ }^{1}$ Hunger has also been shown to have effects in the very short run: In an experimental study, by Aarøe and Peterson (2013) respondents with low glucose levels show stronger support for social welfare.
} 


\section{Methods}

\subsection{Data}

We focus in this research on Germany because a high share of the German population was affected by regulated food supply during and after WWII - including especially low levels of caloric rations after WWII that have been shown to be associated with severe hunger (Kesternich et al., 2015). Our study relies on the possibility to match measures of childhood exposure to hunger to adult preference measures of trust.

Measures of adult trust are contained in the German Socio-Economic Panel (SOEP), an, annual survey of the German population conducted since $1984 .^{2}$ The SOEP has the advantage that each wave is representative of the German population. Furthermore, a rich set of background measures, such as biographic and demographic information, education, and employment histories, are available. However, the panel does not contain direct information on the experience of hunger. Therefore, we enrich the SOEP data with historical data on official daily caloric rations during and after WWII. The historical data provide regional as well as temporal variation in caloric restrictions, and we link them to individual-level data in the SOEP using the month of birth and state of residence in childhood.

\subsection{Measures}

Measures of trust. Survey measures of trust preferences are contained in the 2003 wave of the SOEP. Specifically, respondents were asked for their assessments of the following three statements regarding trust: (A) On the whole one can trust people. (B) Nowadays one can't rely on anyone. (C) If one is dealing with strangers, it is better to be careful before one can trust them.

\footnotetext{
${ }^{2}$ Further information on the SOEP can be obtained online (http://www.diw.de/en/soep).
} 
Respondents answer each question on a four-point scale from 1 (totally agree), 2 (agree slightly), 3 (disagree slightly) to 4 (totally disagree). These trust questions are similar to those used in the General Social Survey ${ }^{3}$ and the World Values Survey ${ }^{4}$

For the SOEP, these earlier trust questions have been refined by Naef and Schupp (2009) to address a critique by Glaeser et al. (2000). Glaeser et al. criticize that these earlier measures are "vague, abstract, and hard to interpret." They integrate survey measures of trust with experimental trust games and find that these standard attitudinal questions do not predict actual behavior in these trust experiments (but rather trustworthiness). Naef and Schupp (2009) develop a new survey measure of trust incorporating the three before mentioned questions. In doing so, they concentrate on James Coleman's concept of trust (Coleman, 1990) which considers trust rather as a form of behavior than a personal characteristic or trait. They show that the three trust questions used in the SOEP provide a valid and reliable measure of trust in strangers (in contrast to trust in institutions and known others) and correlate with behavior in an incentivized trust game. In this respect, this form of trust appears especially relevant for human interactions. The behavioral relevance of this trust measure has been shown by Fehr et al. (2002). They combine the three aforementioned questions by means of factor analysis and show that this combined measure is a significant predictor of the amount that a first-mover sends to the other player in an incentive compatible trust game. Following Fehr et al. (2002) and Dohmen et al. (2012) we combine the answers to the three survey questions into a single trust measure by principal component analysis and standardize the resulting variable. A higher value for this constructed

\footnotetext{
3 “Generally speaking, would you say that most people can be trusted or that you can't be too careful in dealing with people? - Most people can be trusted / Can't be too careful."

4 "Generally speaking, would you say that most people can be trusted or that you need to be very careful in dealing with people? - Most people can be trusted / Need to be very careful."
} 
measure is associated with a higher willingness to trust others. We construct these measures for individuals potentially exposed to hunger in childhood.

Measures of childhood exposure to hunger. Since the beginning of WWII, food production and distribution in Germany was organized centrally with yearly updates of caloric rations. Food and many other things could only be bought using food stamps. A food stamp could, for instance, indicate that one would be allowed (among others) to buy four pounds of bread and 62 grams of fat per week, as well as one egg per month. After the end of WWII, the administrations of the four occupation zones (British, U.S., French, and Soviet) separately set levels of caloric rations and updated them monthly. Food rationing was not eliminated until 1949 in the former British, U.S., and French zones, which form the Federal Republic of Germany, and 1956 in the German Democratic Republic.

Severe famine conditions in Germany were initially reported in the summer of 1945 (Farquharson, 1985), continued through the first years of the Allied occupation, and lasted until 1948. The famine was caused by a combination of supply-side reasons (missing inputs like seeds and fertilizer, missing workforce and machinery as well as losing the pre-war Eastern parts - the so-called "food basket" for Germany), demand-side reasons (increased population through an influx of refugees from the former Eastern parts of the German Reich), breakdowns in trade and transport within Germany, and the organization and governance of the occupying governments (see Kesternich et al. 2014 for further information).

In this study, we use the monthly area-dependent caloric measures from January 1929 to December 1971 (Kesternich et al., 2015). For the time before 1939 when food supply was not restricted, we use average caloric intake per day from the League of Nations for Germany (Liebe, 
1947). ${ }^{5}$ From 1939 until the end of WWII, daily caloric rations did not differ by area, and new caloric rations were set in September.

After the end of the war, caloric rations were updated every four weeks in all but the Soviet zone (Schwarzer, 1995). Rationing was eliminated in July 1948 in the Western zones (Rothenberger, 1980) and not before 1956 in the Eastern zone (Schwarzer, 1995). Figure 1 illustrates this source of regional as well as temporal variation in caloric rations by zone that we exploit in our study. Caloric rations dropped significantly in all zones early in 1945, with a most pronounced drop in the French and U.S. zone. It took much longer for the caloric rations to be back at pre-war levels in the Soviet occupation zone.

Official caloric rations are highly consistent with self-reports of experienced hunger (Kesternich et al., 2015). We compared our collected official caloric rations to self-reports on the existence and duration of experienced hunger that are included in SHARELIFE. SHARELIFE is a retrospective life history survey included in the cross-national European panel survey SHARE that, however, does not include any measures of trust. ${ }^{6}$ We observe a clear relationship between the temporal pattern of caloric rations and self-reported hunger. When caloric rations were not restricted yet in 1938, average daily caloric intake was about $3100 \mathrm{kcal}$ while about $1 \%$ of the sample reported hunger. In 1944, caloric rations were set at about $1700 \mathrm{kcal}$ per day and about $10 \%$ of the sample reported hunger. When the caloric rations drop to about $1000 \mathrm{kcal}$ in 1945 , we observe a spike in self-reported hunger at about $20 \%$. In 1950, caloric rations were mostly back at pre-war levels (except for the Eastern part) and self-reported hunger decreased to about 5\% (Kesternich et al., 2015).

\footnotetext{
5 Reported and recommended caloric rations were about $3100 \mathrm{kcal}$ per day (Liebe, 1947).

${ }^{6}$ For a detailed description of SHARE and SHARELIFE see http://www.share-project.org/.
} 
As the government and the occupying administrations set caloric rations independently, the sources of restricted food supply were exogenous to the individual. Moreover, we have shown that the exposure to hunger is independent of socio-economic status (Kesternich et al., 2015).

To investigate heterogeneous effects of hunger episodes at different stages of childhood, we generate age-specific average daily caloric intakes that depend on the month of birth as well as residence in childhood. We concentrate on being exposed to hunger at ages 0-3 (infant), 4-7 (child), and 8-16 (youth) and further explore the overall exposure at all ages 0-16. For instance, for somebody born in January 1940 and spending childhood in the part of Germany associated with the Soviet zone after WWII, we construct a calorie measure for ages 0-3 taking the average of caloric rations set between January 1940 and December 1943 within this area. In addition, we construct a measure for age-specific variability in daily caloric rations in a similar procedure calculating the standard deviation of the exposed caloric rations at the respective ages depending again on the month of birth and residence in childhood.

One potential concern with our measure of caloric supply is that there were separate rations for adults and children. Moreover, very young children were breastfed. We did not find any quantitative information on how the combined rations of all family members were shared among them. Thus, as the adult and child rations tend to be highly correlated, either could be used as a proxy for the amount of calories individuals in the age groups relevant for our paper actually received. We decided to use the adult rations because this seems to be easier to compare across regions and over time.

\subsection{Statistical analysis}

We estimate ordinary least squares (OLS) regression models in which the dependent variable is the standardized measure of trust obtained from the three survey questions by principal 
component analysis. To estimate the effect of exposure to hunger in childhood on trust preferences, our key explanatory variables are the average as well as the standard deviation of daily caloric intake at ages $0-16,0-3,4-7$ and $8-16$. In addition to analyzing the association between early life hunger and later life trust for the general population, we investigate the association separately for those growing up in an urban and rural environment. We estimate all models using robust SEs clustered by month of birth $\times$ occupation zone at childhood.

We construct our analytic data set from the 2003 wave of the SOEP, which includes the trust measure. We select 7,941 observations of those who participated in this wave; the selection criteria are possible exposure to WWII - that is birth years 1929 to 1955 and being born in Germany or immigrated prior to 1949 ("full sample" hereafter). Exposure to restricted food supply at different ages in childhood varied by residence in the respective occupational zones as well as by month of birth. We merge the SOEP observations with our hunger exposure measure using the state of residence to identify the relevant occupation zone and the month of birth.

Generally, the boundaries of the three Western occupation zones were defined at the Yalta Conference in 1945 to coincide with borders of the pre-1937 states (Länder) which in turn coincide with the borders of the post-war states (Bundesländer) of the Federal Republic. The only exception is the region that in 1951 became Baden-Württemberg. As the majority of the population lived in the US zone (it contained the three largest cities Stuttgart, Karlsruhe and Mannheim), and as we only have information on the state where individuals lived in childhood according to the current boundaries, we assigned all those from Baden-Württemberg to the US zone. See Appendix Table A.1 for the definition of occupation zones. 
We obtain information on the state of residence in childhood using several mechanisms. First, the SOEP contains a question in 2012 about the town in which the respondent was born. ${ }^{7}$ We obtain data on the corresponding state of residence and use this information for those individuals for which the state of residence can be matched to the indicated city with certainty. This information is available for 3,604 individuals (about $45 \%$ ) of the full sample.

Second, we construct a proxy of the state of residence at childhood using two further sources of information. The SOEP contains a question measuring whether the respondent is still living in the same city or area where he or she spent the majority of childhood up to age 15 . If the respondent indicates either "Yes, I still do" or "Yes, I have moved back," the respondent's current state of residence provides information on the state of residence in childhood (available for $51 \%$ of the full sample). ${ }^{8}$

Furthermore, the SOEP collects information on the federal state of last school attendance (available for $46 \%$ of the full sample). We combine the information about the current residency matching the area of childhood as well as the state of school attendance and construct a measure for the state of residence in childhood giving the former information priority $(N=5,868)$. Comparing this proxy with the reliable state of birth obtained from wave 2012, we find that this information is consistent for about $87 \%$ of those individuals for which both information are available $(N=2,759)$. We focus on those for which information on the state of residence in childhood, data on the month of birth, and the trust measure are available $(N=6,503$, "hunger

\footnotetext{
${ }^{7}$ What city or town were you born in? If there is more than one town with the same name, please also state the name of the nearest city.

8 The estimation sample does not differ substantially from the full sample in terms of mobility. We have information on whether individuals still live where they were raised for $98.46 \%$ of our estimation sample. About $60 \%$ still live where they were raised or have moved back, about $38 \%$ do not live there. In comparison, this information is missing for about $11 \%$ of the full 2003 sample; about $52 \%$ live there or have moved back and $37 \%$ do not live there. These figures do not suggest that differential mobility is a major concern. Moreover, our main results do not differ significantly for those living in the same area as in their childhood or for those with missing information on these variables (results are available in request). Further, Bauer et al. (2013, p. 1004) write: "Despite the post-war confusion, the geographical mobility of natives appears to have been relatively low between 1939 and 1950. According to the German population census of September 1950, the vast majority (95.9\%) of those who had lived in West Germany already before the war did not reallocate from one federal state to another between 1939 and $1950 . “$
} 
sample" hereafter). Note that during the hunger period (from 1945 to 1950), Germans were prohibited to relocate within the country (and abroad) by moving restrictions, so that moving in response to the caloric rations was not an option.

The average calorie measures are divided by 1000, and their signs are reversed so that a higher value is associated with a higher exposure to lower caloric rations that would imply more hunger. For example, a change in average daily caloric rations within a specified period in childhood from 2000 to 1500 calories translates into a change from -2 to -1.5 in our transformed variable. To ensure the comparability of the caloric measures based on the average exposure to hunger and the variability in caloric rations, we also divided the standard deviation by 1000 . In this respect a higher value is associated with a higher variability of caloric rations. ${ }^{9}$

The data set is further enriched with background characteristics. The background measures contain information on the respondent's age, gender, whether growing up in an urban environment (equal to 1 if growing up in a large/medium/small city, equal to 0 if growing up in the countryside), the education level of both parents (higher degree if parent obtained secondary, intermediate, or upper secondary school degree), whether the respondent has any sibling, as well as the father's job position when the respondent was 15 years old (blue-collar, self-employed, white-collar, civil service, died/not working). Table 1 provides descriptive statistics for the full and the hunger sample. We observe that the samples are very similar regarding their means and standard deviations.

\footnotetext{
9 The correlation between the average caloric rations and the variability in caloric rations is 0.870 for age $0-16,0.579$ for age $0-3,0.650$ for age 4-7 and 0.812 for age $8-16$.
} 


\section{Results}

\subsection{Main findings}

Table 2 presents the coefficients from OLS regressions estimating the relationship between the respondent's willingness to trust in adulthood and exposure to hunger in childhood. Our main interest lies in childhood exposure to hunger at ages $0-16$. The first column displays the raw correlation. Subsequent columns sequentially add explanatory variables. In column (2), we control for general background characteristics such as quadratic standardized age, gender, and different occupation zones. We also include a dummy for having grown up in an urban environment, as historically those living in urban areas where more severely affected by the postwar hunger episode, and they might also be different regarding trust in strangers.

In column (3), we additionally include controls for the respondent's socio-economic background proxied by indicators whether each parent has obtained a higher degree of education, whether individual has any siblings and the father's job position. Our previous research (Kesternich et al., 2015) shows that this hunger episode affected all socio-economic classes to the same extent. Strictly speaking, we do not need to control for socio-economic background. However, as we do not have individual-level measures of hunger, including these measures helps to control for trends in the socio-economic background that might also be related to trust. ${ }^{10}$

\footnotetext{
${ }^{10}$ In unreported regressions, we investigated whether the effect of hunger on trust is confounded by the father being absent during childhood We estimated a version of our main specification that includes a dummy variable for respondents whose father died until the age of fifteen. It turns out that neither the main effect nor its interaction with the caloric ration is statistically significant. The results are available on request.
} 
In our main specification (column 3), we find that experiencing hunger (lower caloric rations) significantly reduces our standardized measure for trust. In particular, a decrease in average daily caloric rations by $1000 \mathrm{kcal}$ decreases our standardized trust measure by 0.23 standard deviations (statistically significant at the 5 percent level). We observe the caloric rations in the occupation zone at different ages of the respondent, but we do not observe self-reported hunger in the SOEP. Thus, our estimates present an intention-to-treat effect.

Moreover, we find that individuals in Eastern Germany exhibit less trust in strangers. Thus, there is an Eastern Germany effect over and above the worse caloric rations. This effect which does not change including family background measures has been documented in the literature and interpreted as an effect of communism on preferences (Rainer and Siedler, 2009). Investigating our rich set of family background measures, we observe that individuals with a higher socioeconomic status, which can be seen both from the parents' educational background and the father's job position, exhibit more trust in strangers. These findings are in line with Gächter et al. (2004) who document that trust preferences are higher for individuals with higher socioeconomic status. Furthermore, individuals with siblings appear to have significantly more trust in strangers.

\subsection{Robustness checks}

We perform several robustness checks to investigate whether our findings might be explained by other variables that co-vary with caloric rations at childhood. We present the results of these analyses in Table 3 . One concern is that our results might be driven by the Soviet occupation zone which has experienced, in many dimensions, more dramatic changes than the three western zones during our sample period. To confront this possibility, we conducted two robustness checks. First, we exclude those individuals who lived in the Soviet zone in the post-war period 
from our estimation sample in column (2). ${ }^{11}$ When we estimate the model without these individuals, our main results still hold. Second, we investigate whether our results are driven by differential time trends across zones. When we allow for zone-specific flexible time trends using quadratic polynomials, our main results also hold; see column (3).

In our main analysis, we control for age-specific differences in adult trust using a quadratic specification of standardized age. In columns (4) and (5), we substitute this with a more flexible specification of time-of-birth effects. When we include month of birth fixed effects for the months between January 1929 and December 1955, the signs and magnitudes of the main coefficients remain, but they are not statistically significant anymore. The time-of-birth effects remain significant, however, if we use a cubic polynomial in month of birth. We believe that these findings indicate the sample is too small for a saturated (essentially fully nonparametric) model as the counts in the month cells get very low.

Next, we investigate whether the effects of the caloric rations variable really capture the longterm effects of hunger or rather those of war per se? If the latter were the case, caloric rations would need to vary with war exposure. However, caloric rations varied by occupation zone and over time after the war. The variation in caloric rations reflects various factors that are related to the war but follow more complex regional and temporal patterns. First, as discussed above, the zone borders were artificially created. Second, the rations set by the allied occupation forces reflect the physical scarcity of food - due to the disruption of production caused by war destruction, by the creation of the artificial borders, and by the loss of the Eastern parts of the German Reich that traditionally used to be Germany's "bread basket." Third, the monthly

\footnotetext{
11 In an unreported regression, we investigate whether the effect of hunger on trust is smaller for individuals who lived in the US zone than those who lived in the other zones. We estimated a version of our main specification that includes an interaction between the US occupation zone dummy and the caloric rations. The interaction effect is not significant, and the main effect of caloric rations remains virtually unchanged. The results are available upon request.
} 
variation in caloric rations over time was caused by weather conditions, by the influx of refugees, and most importantly by policy choices of the occupying governments. The latter is also related to the need and willingness to confiscate food, which happened mostly in the French and Soviet zones.

It is also conceivable that the variation in the caloric rations (and thus in hunger) is associated with other factors that influence trust, for example a shortage of heating fuels and an increase in crime rates. As we are not aware of any data that would allow us to isolate the effects of such variables from the effect of hunger per se, in our interpretation they constitute facets of the hardship brought about by a severe hunger episode.

In an additional robustness check, we include a dummy for all individuals who experience WWII (i.e., those born before May 1945) and a dummy for all individuals born during the hunger period (i.e., May 1945 through December 1950 for those living in the US, British or French occupation zone, and May 1945 through December 1957 for those living in the Soviet occupation zone). The results are presented in column (6). The main effect of the caloric rations variable changes only little. Being born before May 1945 has a positive and significant effect on trust, which is perhaps surprising but in line with recent research showing that war experiences might foster cooperation (Bauer et al. 2016). Being born during the hunger episode (i.e. after the end of the war and before December 1950) has a small positive, but insignificant coefficient.

A final open question is whether the level (i.e., the dramatic reduction) or the variance (i.e., insecurity) of calorie supply influence trust. In column (7), we include the standard deviation of our caloric rations measure. We find that the coefficient of the mean caloric rations remains significant and of similar magnitude, while the standard deviation has no significant effect on the 
trust measure. Thus, we conclude that it is the lack of food and not the variation in food supply that determines late-life trust.

\subsection{Pathways between childhood exposure to hunger and adult trust}

We conjecture that the hunger episode has direct effects on trust preferences. Unlike the experience of bombing that seems to have strengthened a feeling of helping and trusting within the affected cities ${ }^{12}$, the experience of extreme food shortage lead to a sense of everybody just fighting for their own survival. Predating the current discussion about trust and its determinants, in his historical analysis of post-war hunger episodes, Rothenberger (1980, p. 175) stresses that in a period of scarcity, when everybody had to fight for survival, "egoistic and querulous" traits crowded out social motivations. In addition, there was strong mistrust in Germany against the occupying governments who were thought to either not be doing their best to relieve the situation or even actively holding back on, or confiscating, food supplies (Schlange-Schöningen, 1955, p. 17ff). Historians call the food policies of the Allies one of "hardness and mistrust" (SchlangeSchöningen, 1955, p 18).

A number of recent papers have shown that the in the short run experience of conflict tends to increase cooperation within those considered part of the own group, and evidence seems to point to a change in preferences rather than a pure change in economic payoffs (Bauer et al., 2016). Bauer et al. (2016) claim that intergroup competition should lead to more cooperation within the group. We also find evidence for this in the positive and significant coefficient of a dummy for having experienced WWII; see specification (6) of Table 2. However, when it comes to fighting for resources, the hunger episode was not an intergroup but a within-group conflict, thus we

\footnotetext{
${ }^{12}$ Friedrich (2002, p. 475) writes: "Everybody pulled everybody out of the rubble, emptied endangered flats, sprinkled with water, threw sand, demolished barracks and fences, the notorious fire-bridges" (our translation). Eitner (1990, p. 444) argues that Hitler's (theoretical) "peoples' community" (Volksgemeinschaft) became a (practical) community of suffering.
} 
would expect lower levels of trust also within the own countrymen. Our findings are also in line with recent findings on the effects of early childhood health in psychology. Pietersen and Aarøe (2015) argue that "low birth weight is utilized as a forecast of a harsh environment, vulnerable condition, or both and, consequently, lowers social trust."

In addition to the direct effects of experiencing hunger on trust preferences, the hunger episode may influence trust through a number of indirect channels. The literature of the long-term effects of hunger has documented negative effects on health as well as education and labor market outcomes (Almond 2011, Barker 1992, Barker 2004, Juerges 2013, van den Berg, 2015). In Table 4, we report the results of regression models that explore some of these potential causal channels, following the ideas put forward in mediation analysis (see, for example, Baron and Kenny, 1986, and MacKinnon et al., 2007).

In Panel A of Table 4, we report reduced-form regressions of two health and one education measure: Being in the top 10 percentile of the number of doctor visits from the GSOEP, a standardized physical health measure (Andersen et al., 2007), and a dummy for a high level of education; descriptive statistics and details on the construction of these variables can be found in Appendix Table A.2. The results of these regressions indicate that experiencing periods of low caloric ration supply leads to significantly worse health outcomes and lowers the probability of having a high education level. Thus, both lower levels of health and education could be pathways from experiencing hunger to having lower levels of trust in adult life.

In Panel B of Table 4, specification (1) shows our preferred specification from Table 2. In the remaining specifications (2)-(4), we added one pathway at a time and finally all pathways at once in specification (5). We find that the coefficient of the caloric rations is about ten percent lower when including all pathways, thus suggesting that some of the effect of the hunger episode goes through health and education. However, a large part of the effect remains, suggesting that there 
are either large direct effects of experiencing hunger on trust or other pathways that we have not explored.

In Table 5, we relate our findings to the literature on the East-West trust difference. When we compare the regression in column (1) which includes our hunger exposure measure to the regression in column (2) which excludes it, we find that about 26 percent of the negative effect of having grown up in Eastern Germany on levels of trust is due to restrictions in caloric rations.

\subsection{Exposure to hunger at different ages}

An important concern in the large literature on the effects of shocks experienced in early childhood on adult outcomes is the identification of "critical periods." In the psychological and experimental economics literatures, adolescence is put forward as an important period for the formation of social preferences and social behavior (van de Bos et al., 2010). Sutter and Kocher (2007) investigate trust and trustworthiness across different age groups. Their youngest age group consists of 8 year old children. They find that trust preferences are already present among 8 year olds, and that they strengthen until about age 20; thereafter, they are basically flat. Kocher (2015) suggests that adult-levels of trust are reached at about 16 years of age. Unfortunately, none of the studies includes participants below 8 years of age. In the SOEP data, we also find an almost flat age profile of trust preferences among older respondents (results available on request).

In this section, we investigate whether there are critical periods for the long-run effects of hunger on trust, which has not been explored in the literature so far. Table 6 presents the coefficients from OLS regressions estimating the relationship between the respondent's willingness to trust and the average daily caloric intake at different ages in childhood (all ages 0-16 as well as specific ages 0-3, 4-7 and 8-16), including the full set of controls. The results for the four exposure ages are shown in columns (1) to (4). 
We find the strongest effects for hunger experienced in childhood if we pool all ages. Investigating specific the specific age groups, we find stronger effects for hunger experienced as a child or in one's youth (at ages 4-7 and 8-16, respectively). The point estimates are largest in the oldest age group. However, the estimates are statistically significant at the 5 percent level only for exposure at ages 4-7. If we include the calorie measures for all specific age groups at the same time (column (5)), we observe a similar pattern and find significant effects only for the age group 4-7. For this age group, a decrease in average daily caloric rations by $1000 \mathrm{kcal}$ decreases our standardized trust measure by 0.06 standard deviations (statistically significant at the 10 percent level).

\section{Discussion and conclusion}

We have shown that exposure to a hunger episode during childhood permanently lowers trust. Investigating different measures of exposure to hunger in childhood, we have shown that the general exposure to hunger rather than the variability of caloric rations was the key factor. The data on trust come from a random sample of the German population in 2003 while the historical exposure data refer to the hunger crisis in Germany after, and mostly immediately after, WWII. Hunger affected all regions and all socio-economic classes, but caloric supplies showed substantial regional and temporal variation.

Our results provide a new explanation for the substantial variation in trust preferences that has been observed in several studies. While previous research has shown that trust preferences can be altered in the short-run through the experience of violence, our data suggest that a large shock in a person's childhood can permanently alter trust preferences. While research has demonstrated that trust is a relatively stable adult trait (Caspi and Roberts, 2001), our research deals with the early childhood formation of trust. Its subsequent stability in adulthood is consistent with our 
perspective. Our results are also in line with other studies showing that childhood experiences can have long-run effects on preferences and expectations.

We discussed that trust plays an important role for human interactions both in the interpersonal and economic context. Considering our results, we would like to stress that the long-run consequences of war might be underestimated when being reduced to financial dimensions due to destruction of buildings, infrastructure, businesses, and so forth. A further dimension to keep in mind should be "soft factors" like trust that affect interactions within society that play a role in the economic area (negotiations, transactions, teamwork at the workplace), but also the private area (interactions with neighbors, finding friends, finding a partner). The large-scale consequences of such shock-induced preference changes remain scope for future research.

Our findings provide a new perspective on the seminal work of Barker (1992) who emphasizes that the largest impact of childhood nutrition shocks should be concentrated among the very young. However, Barker studies biological impacts of under-nutrition on health, while we emphasize the behavioral channel, namely, long-term effects on preferences. Our results can either mean that older ages are the sensitive periods for the foundation trust preferences, or that younger children were protected from the hunger episode. The former interpretation would be in line with recent evidence from Sutter and Koch (2007) who measure trust preferences at different ages and find that "trust increases almost linearly from early childhood to early adulthood." One has to note, though, that their study excludes the very young. The latter interpretation is consistent with very young children being better protected as they were still being breastfed.

This finding also adds to the discussion on long-terms effects of war and conflicts. First, experiments conducted around the 2006 Israel-Hezbollah War show that intra-group cooperation was increased during times of conflict. Here, we use a large random sample of a population to 
show that trust in strangers (in contrast to intra-group preferences as in Gneezy and Fessler, 2012) was decreased and that these effects were long-lasting and thus are still present more than 50 years after the experienced shock. Prior research on the long-term effects of WWII show that health, marriage, and labor market outcomes of those surviving are negatively affected (Juerges, 2013; Kesternich et al., 2014). If hardship that comes with violent conflicts, in our case hunger, permanently alters preferences, including trust, that are to a certain extent inherited within families (Dohmen et al., 2012; Ljunge, 2014), then this could perpetuate negative equilibriums. 


\section{References}

Aarøe, L., M.B. Petersen. 2013. Hunger games: Fluctuations in blood glucose levels influence social welfare support. Psychological Science, 24(12), 2550-2556.

Almond, D., J. Currie. 2011. Killing me softly: The fetal origins hypothesis. Journal of Economic Perspectives, 25(3), 153-172.

Barker, D.J.P. 1992. Fetal and infant origins of adult disease. London: BMJ Publishing Group.

Barker, D.J.P. 2004. The developmental origins of adult disease. Journal of the American College of Nutrition, 23(6), 588S-595S.

Bauer, M., C. Blattman, J. Chytilová, J. Henrich, E. Miguel and T. Mitts. 2016. Can war foster cooperation? Journal of Economic Perspectives, 30(3), 249-74.

Bauer, M., A. Cassar, J. Chytilová, J. Henrich. 2014. War's enduring effects on the development of egalitarian motivations and in-group biases. Psychological Science, 25(1), 47-57.

Bauer, T. K., S. Braun, M. Kvasnicka. 2013. The economic integration of forced migrants: Evidence for Post-War Germany. Economic Journal, 123, 998-1024.

Bertoni, M. 2015. Hungry today, unhappy tomorrow? Childhood hunger and subjective wellbeing later in life. Journal of Health Economics, 40, 40-53.

Bigoni, M., S. Bortolotti, M. Casari, D. Gambetta, F. Pancotto. 2015. Amoral familism, social capital, or trust? The behavioral foundations of the Italian North-South divide. Economic Journal, forthcoming.

Black, S., P.J. Devereux, P. Lundborg, K. Majlesi. 2015. On the origins of risk-taking. Unpublished working paper. 
Caspi, A., B.W. Roberts. 2001. Personality development across the life course: The argument for change and continuity. Psychological Inquiry, 12(2), 49-66.

Coleman, J.S. 1990. Foundations of social theory. Cambridge, MA: Belknap Press of Harvard University Press.

Dohmen, T., A. Falk, D.B. Huffman, U. Sunde. 2012. The intergenerational transmission of risk and trust attitudes. Review of Economic Studies, 79(2), 645-677.

Eitner, H.J. 1990. Hitlers Deutsche: Das Ende eines Tabus. Gernsbach: Katz.

Elder, G.H. 1998. The life course as development theory. Child Development 69(1), 1-12.

Farquharson, J.E. 1985. The Western allies and politics of food. Agrarian Management in Postwar Germany. Dover, NH: Berg Publishers.

Fehr, E., U. Fischbacher, B. von Rosenbladt, J. Schupp, G.G. Wagner. 2002. A nation-wide laboratory: Examining trust and trustworthiness by integrating behavioral experiments into representative surveys. Journal of Applied Social Science Studies, 122(4), 519-542.

Fehr, E., K. Hoff. 2011. Introduction: Tastes, castes and culture: The influence of society on preferences. Economic Journal, 121, F396-F412.

Friedrich, J. 2002. Der Brand: Deutschland im Bombenkrieg 1940-45. München: Propyläen.

Gächter, S., Herrmann, B., Thöni, C. 2004. Trust, voluntary cooperation, and socio-economic background: Survey and experimental evidence. Journal of Economic Behavior and Organization, 55, 505-531.

Gambetta, D. 2000. Can we trust trust? In: Gambetta, D. (Eds.). Trust: Making and Breaking Cooperative Relations Oxford: University of Oxford Press, 213-227. 
Glaeser, E.L., D.I. Laibson, J.A. Scheinkman, C.L. Soutter. 2000. Measuring trust. Quarterly Journal of Economics, 115(3), 811-846.

Gneezy, A., D.M.T. Fessler. 2012. Conflict, sticks and carrots: War increases prosocial punishments and rewards. Proceedings of the Royal Society B: Biological Sciences, 279(1727), 219-223.

Goodman, A., R. Joyce, J.P. Smith. 2011. The long shadow cast by childhood physical and mental problems on adult life. Proceedings of the National Academy of Sciences, 108(15), 6032-6037.

Guiso, L., P. Sapienza, L. Zingales. 2008. Trusting the stock market. Journal of Finance 63(6), $2557-2600$.

Guiso, L., P. Sapienza, L. Zingales. 2009. Cultural biases in economic exchange. Quarterly Journal of Economics, 124(3), 1095-1131.

Juerges, H. 2013. Collateral damage: educational attainment and labor market outcomes among German war and post-war cohorts. Journal of Health Economics, 32, 286-303.

Kesternich, I., B. Siflinger, J.P. Smith, J. Winter. 2014. The effects of World War II on economic and health outcomes across Europe. Review of Economics and Statistics, 96(1), 103118.

Kesternich, I., B. Siflinger, J.P. Smith, J. Winter. 2015. Individual behavior as a pathway between early-life shocks and adult health: Evidence from hunger episodes in post-war Germany. Economic Journal, 125, F372-F393.

Knack, S., P. Keefer. 1997. Does social capital have an economic payoff? A cross-country investigation. Quarterly Journal of Economics, 112, 1252-1288. 
La Porta, R.F., F. Lopez-de-Silanes, A. Shleifer, R.W. Vishny. 1997. Trust in large organizations. American Economic Review, 87, 333-338.

Liebe, H., 1947. Drei Grundprobleme der deutschen Wirtschaft. In: Deutsches Institut fuer Wirtschaftsforschung (Eds.). Die deutsche Wirtschaft zwei Jahre nach dem Zusammenbruch. Tatsachen und Probleme. Berlin: Nauck.

Ljunge, M. 2014. Trust issues: Evidence on the intergenerational trust transmission among children of immigrants. Journal of Economic Behavior and Organization, 106, 175-196.

Malmendier, U., S. Nagel. 2011. Depression babies: Do macroeconomic experiences affect risktaking? Quarterly Journal of Economics 126, 373-416.

Malmendier, U., S. Nagel. 2016. Learning from inflation experiences. Quarterly Journal of Economics, forthcoming.

Malmendier, U., L.S. Shen. 2015. Experience effects in consumption. Unpublished working paper.

Misztal, B., 1996. Trust in modern societies: The search for the bases of social order. Cambridge, UK: Polity Press.

Naef, M., J. Schupp. 2009. Measuring trust: Experiments and surveys in contrast and combination. SOEP Papers on Multidisciplinary Panel Data Research 167 (The German Socio-Economic Panel (SOEP), Berlin).

Rainer, H., T. Siedler. 2009. Does democracy foster trust? Journal of Comparative Economics $37(2), 251-269$.

Petersen, M. B., L. Aarøe. 2015. Birth weight and social trust in adulthood: Evidence for early calibration of social cognition. Psychological Science, 26(11), 1681-1692. 
Putnam, D., R. Leonardi, Y. Nanetti. 1994. Making democracy work: Civic traditions in modern Italy. Princeton University Press.

Rothenberger, K., 1980. Die Hungerjahre nach dem Zweiten Weltkrieg. Boldt Verlag.

Schlange-Schöningen, H. (1955): Im Schatten des Hungers: Dokumentation zur Ernährungspolitik und Ernährungswirtschaft in den Jahren 1945-1949. Hamburg und Berlin: Verlag Paul Parey.

Schwarzer, O. 1995. Der Lebensstandard in der SBZ/DDR 1945/1989. Jahrbuch für Wirtschaftsgeschichte, 1995(2), 119-145.

Sutter, M., M.G. Kocher. 2007. Trust and trustworthiness across different age groups. Games and Economic Behavior, 59, 364-382.

van den Berg, G., P.J. Pinger, J. Schoch. 2015. Instrumental variable estimation of the causal effect of hunger early in life on health later in life. Economic Journal, forthcoming. 
Figures and Tables

FIGURE 1: VARIATION OF CALORIC RATIONS OVER TIME AND OCCUPATION ZONES

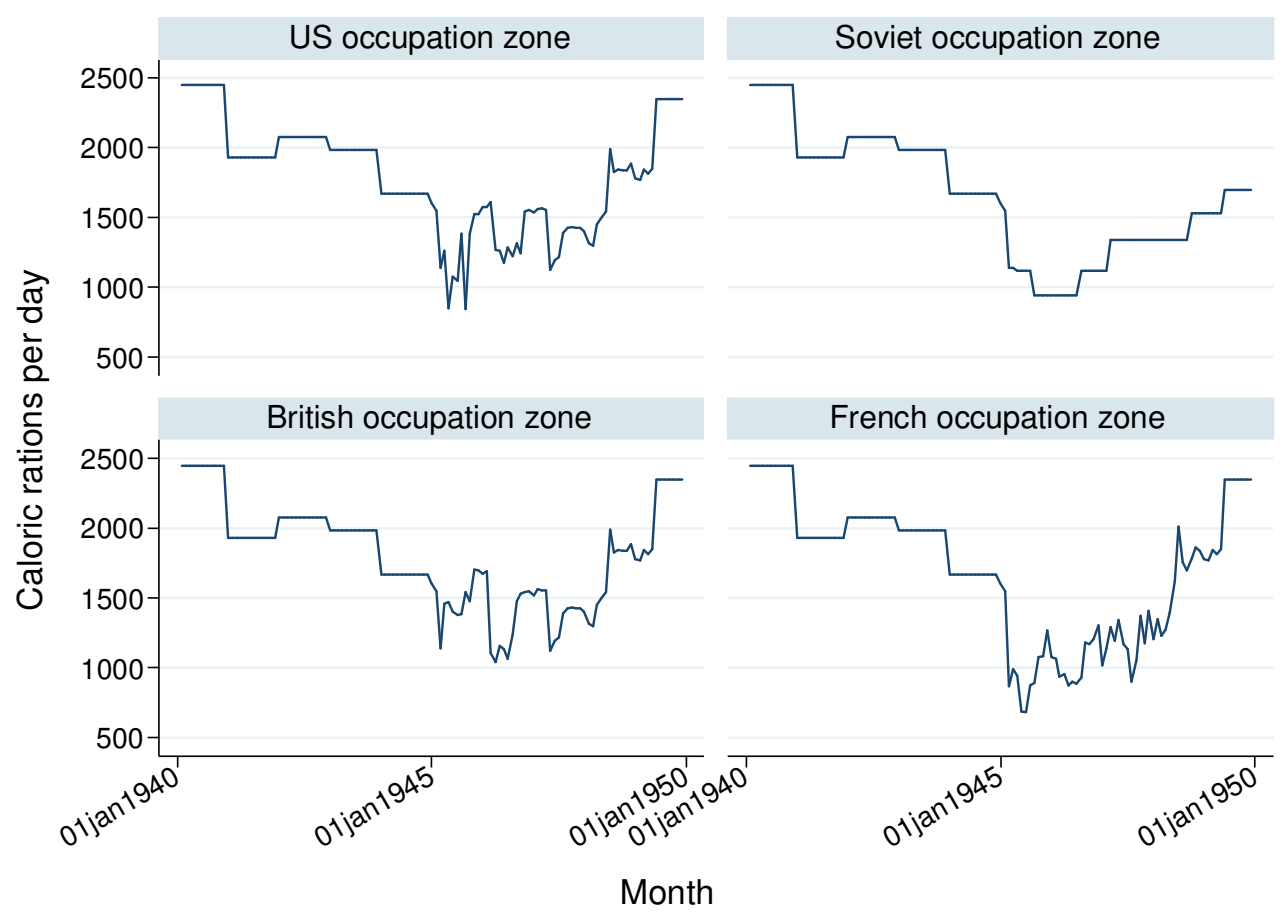

Notes: Figure displays average caloric rations per day for the four occupation zones. 


\begin{tabular}{|c|c|c|c|c|c|c|}
\hline \multirow[b]{2}{*}{ Variable } & \multicolumn{3}{|c|}{ Full sample } & \multicolumn{3}{|c|}{ Hunger sample } \\
\hline & $\mathbf{N}$ & Mean & SD & $\mathbf{N}$ & Mean & SD \\
\hline \multicolumn{7}{|l|}{ Outcome } \\
\hline Willingness to trust, PCA (std.) & 7854 & 0.00 & 1.00 & 6503 & 0.03 & 1.00 \\
\hline \multicolumn{7}{|l|}{ Calorie measures } \\
\hline (Negative) average daily caloric intake at age $0-16$ & & & & 6503 & -2.60 & 0.38 \\
\hline (Negative) average daily caloric intake at age $0-3$ & & & & 6503 & -2.48 & 0.61 \\
\hline (Negative) average daily caloric intake at age 4-7 & & & & 6503 & -2.48 & 0.66 \\
\hline (Negative) average daily caloric intake at age 8-16 & & & & 6503 & -2.71 & 0.52 \\
\hline Standard deviation daily caloric intake at age $0-16$ & & & & 6503 & 0.47 & 0.28 \\
\hline Standard deviation daily caloric intake at age $0-3$ & & & & 6503 & 0.20 & 0.17 \\
\hline Standard deviation daily caloric intake at age 4-7 & & & & 6503 & 0.18 & 0.17 \\
\hline Standard deviation daily caloric intake at age 8-16 & & & & 6503 & 0.24 & 0.27 \\
\hline \multicolumn{7}{|l|}{ Control variables } \\
\hline Male & 7941 & 0.50 & 0.50 & 6503 & 0.51 & 0.50 \\
\hline Age & 7941 & 59.82 & 7.54 & 6503 & 59.26 & 7.36 \\
\hline Urban area (childhood) & 7795 & 0.60 & 0.49 & 6426 & 0.61 & 0.49 \\
\hline US zone (childhood) & 6713 & 0.27 & 0.44 & 6503 & 0.27 & 0.44 \\
\hline UK zone (childhood) & 6713 & 0.33 & 0.47 & 6503 & 0.33 & 0.47 \\
\hline French zone (childhood) & 6713 & 0.06 & 0.23 & 6503 & 0.06 & 0.24 \\
\hline Soviet zone (childhood) & 6713 & 0.34 & 0.47 & 6503 & 0.34 & 0.48 \\
\hline Father: Lower degree & 7231 & 0.80 & 0.40 & 5962 & 0.80 & 0.40 \\
\hline Father: Higher degree & 7231 & 0.20 & 0.40 & 5962 & 0.20 & 0.40 \\
\hline Mother: Lower degree & 7339 & 0.86 & 0.35 & 6041 & 0.85 & 0.36 \\
\hline Mother: Higher degree & 7339 & 0.14 & 0.35 & 6041 & 0.15 & 0.36 \\
\hline Any siblings & 7867 & 0.84 & 0.37 & 6454 & 0.84 & 0.37 \\
\hline Father: Blue-collar/agricultural & 6959 & 0.45 & 0.50 & 5803 & 0.45 & 0.50 \\
\hline Father: Self-employed & 6959 & 0.15 & 0.36 & 5803 & 0.16 & 0.37 \\
\hline Father: White-collar & 6959 & 0.19 & 0.40 & 5803 & 0.20 & 0.40 \\
\hline Father: Civil service & 6959 & 0.09 & 0.29 & 5803 & 0.09 & 0.29 \\
\hline Father: Died / not working & 6959 & 0.11 & 0.31 & 5803 & 0.10 & 0.31 \\
\hline
\end{tabular}

Notes: The full sample contains individuals that participated in wave 2003 of the SOEP, were born between 1929 and 1955 and have German nationality or immigrated prior to 1949. The hunger sample contains individuals for which we can construct the trust measure and have data on the month of birth and state of residence in childhood via (1) reliable information about the state of birth contained in wave 2012, or a proxy using (2) the state in which they spent the majority of their childhood up to the age 15 or, if not possible, (3) the state in which they last attended school. 
TABLE 2: OLS REGRESSION OF ADULT TRUST ON CHILDHOOD EXPOSURE TO HUNGER

\begin{tabular}{|c|c|c|c|}
\hline \multirow[b]{2}{*}{ Regressors } & \multicolumn{3}{|c|}{ Dependent variable: Adult trust } \\
\hline & (1) & (2) & (3) \\
\hline \multirow[t]{2}{*}{ (Negative) average daily caloric intake at age $0-16$} & $--.184 * * *$ & $--.201 * *$ & $--.225^{* *}$ \\
\hline & $(.034)$ & $(.097)$ & $(.096)$ \\
\hline \multicolumn{4}{|l|}{ Basic controls } \\
\hline \multirow[t]{2}{*}{ Male } & & .006 & .002 \\
\hline & & $(.024)$ & $(.024)$ \\
\hline \multirow[t]{2}{*}{ Age/10 } & & .277 & .081 \\
\hline & & $(.459)$ & $(.454)$ \\
\hline \multirow[t]{2}{*}{$(\text { Age } / 10)^{2}$} & & --.019 & --.001 \\
\hline & & $(.036)$ & $(.035)$ \\
\hline \multirow[t]{2}{*}{ Urban area (childhood) } & & $.080 * * *$ & .022 \\
\hline & & $(.027)$ & $(.028)$ \\
\hline \multirow[t]{2}{*}{ Urban area missing (childhood) } & & .075 & $.175^{*}$ \\
\hline & & $(.097)$ & $(.106)$ \\
\hline \multirow[t]{2}{*}{ US zone (childhood) } & & .026 & .013 \\
\hline & & $(.030)$ & $(.030)$ \\
\hline \multirow[t]{2}{*}{ French zone (childhood) } & & --.028 & --.028 \\
\hline & & $(.057)$ & $(.057)$ \\
\hline \multirow[t]{2}{*}{ Soviet zone (childhood) } & & $--.164 * * *$ & $--.140 * * *$ \\
\hline & & $(.038)$ & $(.037)$ \\
\hline \multicolumn{4}{|l|}{ Family background } \\
\hline \multirow[t]{2}{*}{ Mother: Higher degree } & & & $.138 * * *$ \\
\hline & & & $(.042)$ \\
\hline \multirow[t]{2}{*}{ Father: Higher degree } & & & $.138 * * *$ \\
\hline & & & $(.038)$ \\
\hline \multirow[t]{2}{*}{ Any siblings } & & & $.061 *$ \\
\hline & & & $(.036)$ \\
\hline \multirow[t]{2}{*}{ Father: Self-employed } & & & $.115^{* * * *}$ \\
\hline & & & $(.039)$ \\
\hline \multirow[t]{2}{*}{ Father: White-collar } & & & $.169 * * *$ \\
\hline & & & $(.037)$ \\
\hline \multirow[t]{2}{*}{ Father: Civil service } & & & $.153 * * *$ \\
\hline & & & $(.046)$ \\
\hline \multirow[t]{2}{*}{ Father: Died/not working } & & & $.133 * * *$ \\
\hline & & & $(.045)$ \\
\hline \multirow[t]{2}{*}{ Father: Missing job position } & & & $--.102 * *$ \\
\hline & & & $(.047)$ \\
\hline $\mathbf{N}$ & 6503 & 6503 & 6503 \\
\hline
\end{tabular}

Notes: Values are estimated coefficients (SE) based on the hunger sample. The standardized principal component of agreement with trust questions in 2003 (general trust, reliance on others, need for caution in dealing with strangers) is used as the dependent variable. The regression in column 3 contains dummies for missing observations in parents' education and siblings that are all insignificant. The reference group for the father's job position is blue-collar/agricultural. All estimates are based on OLS regressions with robust standard errors clustered at the month of birth $\times$ occupation zone at childhood level.

*** Significant at the 1 percent level.

** Significant at the 5 percent level.

* Significant at the 10 percent level. 
TABLE 3: ROBUSTNESS CHECKS

\begin{tabular}{|c|c|c|c|c|c|c|c|}
\hline Regressors & Baseline & $\begin{array}{l}\text { Excluding } \\
\text { soviet zone }\end{array}$ & $\begin{array}{l}\text { Interaction } \\
\text { age } x \text { occu- } \\
\text { pation } \\
\text { zones } \\
\text { (3) }\end{array}$ & $\begin{array}{c}\begin{array}{c}\text { Month of } \\
\text { birth fixed } \\
\text { effects }\end{array} \\
\text { (4) }\end{array}$ & $\begin{array}{c}\text { 3rd order } \\
\text { polynomial } \\
\text { birth } \\
\text { month } \\
(5)\end{array}$ & WWII & $\begin{array}{c}\text { Variation } \\
\text { in caloric } \\
\text { intake } \\
\text { (7) }\end{array}$ \\
\hline \multirow[t]{2}{*}{$\begin{array}{l}\text { (Negative) average daily caloric } \\
\text { intake at age } 0-16\end{array}$} & $--.225 * *$ & $--.265 * *$ & $--.250 * *$ & --.158 & $--.120 * * *$ & $--.330 * *$ & $--.230 * *$ \\
\hline & $(.096)$ & $(.121)$ & $(.103)$ & $(.235)$ & $(.036)$ & $(.143)$ & $(.096)$ \\
\hline \multirow[t]{2}{*}{$\begin{array}{l}\text { Standard deviation daily caloric } \\
\text { intake at age } 0-16\end{array}$} & & & & & & & .052 \\
\hline & & & & & & & $(.116)$ \\
\hline \multirow[t]{2}{*}{ Age/10 } & .081 & .045 & .402 & & & --.087 & --.058 \\
\hline & $(.454)$ & $(.493)$ & $(.593)$ & & & $(.638)$ & $(.560)$ \\
\hline \multirow[t]{2}{*}{$(\mathrm{Age} / 10)^{2}$} & --.001 & .004 & --.025 & & & .009 & .009 \\
\hline & $(.035)$ & $(.038)$ & $(.047)$ & & & $(.049)$ & $(.043)$ \\
\hline \multirow[t]{2}{*}{ US zone (childhood) } & .013 & .003 & 3.085 & .013 & .012 & .014 & .012 \\
\hline & $(.030)$ & $(.030)$ & (2.194) & $(.025)$ & $(.030)$ & $(.030)$ & $(.030)$ \\
\hline \multirow[t]{2}{*}{ French zone (childhood) } & --.028 & --.039 & --.599 & --.035 & --.030 & --.025 & --.030 \\
\hline & $(.057)$ & $(.057)$ & $(4.066)$ & $(.054)$ & $(.057)$ & $(.057)$ & $(.057)$ \\
\hline \multirow[t]{2}{*}{ Soviet zone (childhood) } & $--.140 * * *$ & & --.131 & $--.157 * * *$ & $--.163 * * *$ & $--.130 * * *$ & $--.142 * * *$ \\
\hline & $(.037)$ & & $(2.225)$ & $(.058)$ & $(.032)$ & $(.050)$ & $(.038)$ \\
\hline \multirow[t]{2}{*}{ Age/10 x US zone } & & & --1.018 & & & & \\
\hline & & & $(.737)$ & & & & \\
\hline \multirow[t]{2}{*}{$(\text { Age } / 10)^{2} \times$ US zone } & & & .083 & & & & \\
\hline & & & $(.061)$ & & & & \\
\hline \multirow[t]{2}{*}{ Age/10 x Soviet zone } & & & .034 & & & & \\
\hline & & & $(.746)$ & & & & \\
\hline \multirow[t]{2}{*}{$(\text { Age } / 10)^{2} \times$ Soviet zone } & & & --.006 & & & & \\
\hline & & & $(.062)$ & & & & \\
\hline \multirow[t]{2}{*}{ Age/10 x French zone } & & & .266 & & & & \\
\hline & & & (1.369) & & & & \\
\hline \multirow[t]{2}{*}{$(\text { Age } / 10)^{2} \times$ French zone } & & & --.028 & & & & \\
\hline & & & $(.114)$ & & & & \\
\hline \multirow[t]{2}{*}{ Month of birth (std.) } & & & & & --.002 & & \\
\hline & & & & & $(.001)$ & & \\
\hline \multirow[t]{2}{*}{ Month of birth (std.) ${ }^{2}$} & & & & & $.000 *$ & & \\
\hline & & & & & $(.000)$ & & \\
\hline \multirow[t]{2}{*}{ Month of birth (std.) ${ }^{3}$} & & & & & $--.000 *$ & & \\
\hline & & & & & $(.000)$ & & \\
\hline \multirow[t]{2}{*}{ Born before May 1945} & & & & & & $.173^{* *}$ & \\
\hline & & & & & & $(.087)$ & \\
\hline \multirow[t]{2}{*}{$\begin{array}{l}\text { Born after WWII, but before } \\
\text { end of hunger episode }\end{array}$} & & & & & & .051 & \\
\hline & & & & & & $(.059)$ & \\
\hline Further controls & $\mathrm{X}$ & $\mathrm{X}$ & $\mathrm{X}$ & $\mathrm{X}$ & $\mathrm{X}$ & $\mathrm{X}$ & $\mathrm{X}$ \\
\hline Month of birth FE & & & & $\mathrm{X}$ & & & \\
\hline $\mathbf{N}$ & 6503 & 4266 & 6503 & 6503 & 6503 & 6503 & 6503 \\
\hline
\end{tabular}

Notes: Values are estimated main coefficients (SE) based on the hunger sample. Further controls include gender, growing up in an urban environment, whether each parent has obtained a higher degree (defined as intermediate, technical, or upper secondary school degree), having any siblings, job position of father (blue-collar/agricultural (reference), self-employed, white-collar, civil service, died/not working). All estimates are based on OLS regressions with robust standard errors clustered at the month of birth $\times$ occupation zone at childhood level.

*** Significant at the 1 percent level.

** Significant at the 5 percent level.

* Significant at the 10 percent level. 


\begin{tabular}{|c|c|c|c|c|c|}
\hline Regressors & (1) & $\begin{array}{l}\text { More than } 7 \\
\text { doctor visits } \\
\text { in past } 3 \\
\text { months } \\
\text { (2) }\end{array}$ & $\begin{array}{c}\text { Physical } \\
\text { health score }\end{array}$ & $\begin{array}{l}\text { High degree } \\
\text { in education }\end{array}$ & (5) \\
\hline \multicolumn{6}{|l|}{$\begin{array}{l}\text { Panel A: Potential pathways } \\
\text { (dep. Variable) }\end{array}$} \\
\hline \multirow[t]{2}{*}{$\begin{array}{l}\text { (Negative) average daily caloric intake } \\
\text { at age } 0-16\end{array}$} & & $.047 *$ & $--1.788^{*}$ & $--.145 * * *$ & \\
\hline & & $(.027)$ & $(.937)$ & $(.043)$ & \\
\hline \multicolumn{6}{|l|}{$\begin{array}{l}\text { Panel B: Pathways between } \\
\text { childhood exposure to hunger and } \\
\text { adult trust (dep. variable) }\end{array}$} \\
\hline \multirow[t]{2}{*}{$\begin{array}{l}\text { (Negative) Average daily caloric } \\
\text { intake at age } 0-16\end{array}$} & $--.225^{* *}$ & $--.206^{* *}$ & $--.250 * * *$ & $--.187 * *$ & $--.211 * *$ \\
\hline & $(.096)$ & $(.094)$ & $(.096)$ & $(.095)$ & $(.095)$ \\
\hline \multirow[t]{2}{*}{$\begin{array}{l}\text { More than } 7 \text { doctor visits in past } 3 \\
\text { months }\end{array}$} & & $--.248 * * *$ & & & $--.149 * * *$ \\
\hline & & $(.043)$ & & & $(.044)$ \\
\hline \multirow[t]{2}{*}{ Physical health score } & & & $.014 * * *$ & & $.010 * * *$ \\
\hline & & & $(.001)$ & & $(.001)$ \\
\hline \multirow[t]{2}{*}{ High degree in education } & & & & $.311 * * *$ & $.268 * * *$ \\
\hline & & & & $(.027)$ & $(.028)$ \\
\hline Further controls & $\mathrm{X}$ & $\mathrm{X}$ & $\mathrm{X}$ & $\mathrm{X}$ & $\mathrm{X}$ \\
\hline $\mathbf{N}$ & 6503 & 6477 & 6254 & 6496 & 6226 \\
\hline
\end{tabular}

Notes: Values are estimated coefficients (SE) based on the hunger sample. The regression in the first column is identical to the regression in column 3 of Table 2. Further controls include gender, standardized age and age ${ }^{2}$, growing up in an urban environment, occupation zone fixed effects, whether each parent has obtained a higher degree (defined as intermediate, technical, or upper secondary school degree), having any siblings, job position of father (blue-collar/agricultural (reference), self-employed, white-collar, civil service, died/not working). All estimates are based on OLS regressions with robust standard errors clustered at the month of birth $\times$ occupation zone at childhood level.

*** Significant at the 1 percent level.

** Significant at the 5 percent level.

* Significant at the 10 percent level. 
TABLE 5: DISTINGUISHING BETWEEN EFFECTS OF CHILDHOOD EXPOSURE TO HUNGER FROM LIVING IN THE GDR

\begin{tabular}{|c|c|c|}
\hline Regressors & $\begin{array}{l}\text { With calorie measure } \\
\text { (1) }\end{array}$ & $\begin{array}{c}\text { Without calorie } \\
\text { measure } \\
\text { (2) }\end{array}$ \\
\hline (Negative) average daily caloric intake at age $0-16$ & $\begin{array}{l}--.225 * * \\
(.096)\end{array}$ & \\
\hline Occupation zones & & \\
\hline US zone (childhood) & $\begin{array}{l}.013 \\
(.030)\end{array}$ & $\begin{array}{c}.012 \\
(.030)\end{array}$ \\
\hline French zone (childhood) & $\begin{array}{l}--.028 \\
(.057)\end{array}$ & $\begin{array}{l}--.034 \\
(.057)\end{array}$ \\
\hline Soviet zone (childhood) & $\begin{array}{c}--.140 * * * \\
(.037)\end{array}$ & $\begin{array}{c}--.188^{* * * *} \\
(.031)\end{array}$ \\
\hline $\begin{array}{l}\text { Further controls } \\
\mathrm{N}\end{array}$ & $\begin{array}{c}\mathrm{X} \\
6503\end{array}$ & $\begin{array}{c}\mathrm{X} \\
6503\end{array}$ \\
\hline
\end{tabular}

Notes: Values are estimated coefficients (SE) based on the hunger sample. The regression in the first column is identical to the regression in column 3 of Table 2. Further controls include gender, standardized age and age $^{2}$, growing up in an urban environment, whether each parent has obtained a higher degree (defined as intermediate, technical, or upper secondary school degree), having any siblings, job position of father (blue-collar/agricultural (reference), self-employed, white-collar, civil service, died/not working). All estimates are based on OLS regressions with robust standard errors clustered at the month of birth $\times$ occupation zone at childhood level.

*** Significant at the 1 percent level.

** Significant at the 5 percent level.

* Significant at the 10 percent level. 
TABLE 6: ROLE OF CHILDHOOD EXPOSURE TO HUNGER AT DIFFERENT AGES

\begin{tabular}{|c|c|c|c|c|c|}
\hline \multirow[b]{2}{*}{ Regressors } & \multirow{2}{*}{$\begin{array}{c}\text { All ages } \\
\text { (1) }\end{array}$} & \multicolumn{3}{|c|}{ "Specific ages (infant, child, youth) } & \multirow{2}{*}{$\begin{array}{c}\text { Joint } \\
\text { estimation } \\
(5)\end{array}$} \\
\hline & & (2) & (3) & (4) & \\
\hline \multirow[t]{2}{*}{ (Negative) average daily caloric intake at age 0-16 } & $--.225 * *$ & & & & \\
\hline & $(.096)$ & & & & \\
\hline \multirow[t]{2}{*}{ (Negative) average daily caloric intake at age $0-3$} & & .014 & & & --.031 \\
\hline & & $(.035)$ & & & $(.051)$ \\
\hline \multirow[t]{2}{*}{ (Negative) average daily caloric intake at age 4-7 } & & & $--.061 * *$ & & $--.055^{*}$ \\
\hline & & & $(.029)$ & & $(.030)$ \\
\hline \multirow[t]{2}{*}{ (Negative) average daily caloric intake at age 8-16 } & & & & --.092 & --.124 \\
\hline & & & & $(.062)$ & $(.091)$ \\
\hline Further controls & $\mathrm{X}$ & $\mathrm{X}$ & $\mathrm{X}$ & $\mathrm{X}$ & $\mathrm{X}$ \\
\hline F-test: Joint significance & & & & & .111 \\
\hline $\mathbf{N}$ & 6503 & 6503 & 6503 & 6503 & 6503 \\
\hline
\end{tabular}

Notes: Values are estimated main coefficients (SE) based on the hunger sample. Further controls include gender, standardized age and age $^{2}$, growing up in an urban environment, occupation zone fixed effects, whether each parent has obtained a higher degree (defined as intermediate, technical, or upper secondary school degree), having any siblings, job position of father (blue-collar/agricultural (reference), self-employed, white-collar, civil service, died/not working). All estimates are based on OLS regressions with robust standard errors clustered at the month of birth $\times$ occupation zone at childhood level.

$* * *$ Significant at the 1 percent level.

** Significant at the 5 percent level.

* Significant at the 10 percent level. 


\section{Appendix Figures and Tables}

APPENDIX TABLE A.1: DEFINITION OF OCCUPATION ZONES

\begin{tabular}{llll}
\hline \hline US zone & Soviet zone & British zone & French zone \\
\hline Bremen & Berlin & Schleswig-Holstein & Rhineland-Palatinate \\
Hesse & Brandenburg & Hamburg & Lower Saxony \\
Baden-Wuerttemberg & Mecklenburg Western Pomerania & North Rhine-Westphalia \\
Bavaria & Saxony & \\
& Saxony-Anhalt & & \\
& Thuringia & & \\
& GDR, without further details & & \\
\hline \hline
\end{tabular}


APPENDIX TABLE A.2: DESCRIPTIVE STATISTICS OF PATHWAYS

\begin{tabular}{|c|c|c|c|}
\hline \multirow[b]{2}{*}{ Variable } & \multicolumn{3}{|c|}{ Hunger sample } \\
\hline & $\mathbf{N}$ & Mean & SD \\
\hline \multicolumn{4}{|l|}{ Pathways } \\
\hline More than 7 doctor visits in past 3 months & 6477 & 0.09 & 0.29 \\
\hline Physical health score & 6254 & 47.01 & 9.74 \\
\hline High degree of schooling & 6496 & 0.53 & 0.50 \\
\hline
\end{tabular}

Notes: More than 7 doctor visits is an indicator constructed from information on the number of doctor visits in past 3 months in SOEP wave 2003, marking the highest decile. Physical health score combines questions from the SF-12v2 inventory contained in SOEP wave 2002. A higher value indicates better health. High degree of schooling indicates that respondent has obtained an intermediate/technical or upper secondary school degree (collected via biography questionnaire). 